ks. Adam Olszewski

https://orcid.org/oooo-0003-3069-7518

Uniwersytet Papieski Jana Pawła II w Krakowie

\title{
Prawda a teza Churcha - wyzwanie rzucone tomistom
}

Celem niniejszej pracy jest próba porównania tezy Churcha [dalej: CT] z korespondencyjną koncepcją prawdy [dalej: KKP], a w szczególności porównanie jej z definicją prawdy jako „adaequatio rei et intellectus” [dalej: AIR] w oparciu o elementy filozofii św. Tomasza z Akwinu. Patrząc na to nieco inaczej, można powiedzieć, że jej celem jest próba odtworzenia i wyjaśnienia (eksplanacji) CT w systemie filozoficznym Akwinaty, ze specyficznym wykorzystaniem AIR oraz jego filozofii matematyki. Ponieważ nie doprowadzimy do jakiejś jednoznacznej konkluzji, można powiedzieć, że chcemy postawić pewien problem, który będzie wymagać rozwiązania.

\section{Niektóre ważne źródła tekstowe}

Zwyczajowo, przy ogólnym i pobieżnym ujęciu korespondencyjnej, zwanej również klasyczną, teorii (koncepcji) prawdy podaje się dwa źródła. Pierwszym jest tekst Arystotelesa z Metafizyki: „Twierdzić o Bycie, że nie istnieje, albo Nie-Bycie, że istnieje, jest fałszem; natomiast twierdzić, że Byt istnieje, a Nie-Byt nie istnieje, jest prawdą; tak że kto twierdzi o czymś, że istnieje albo że nie istnieje, powie prawdę albo fałsz" (1011b25) ${ }^{1}$. Wprawdzie Stagiryta w tym tekście dosłownie nie mówi o „korespondencji”, ale wskazuje ogólnie na jakiś rodzaj paraleli pomiędzy wypowiedziami (sądami, zdaniami), a bytem

Arystoteles, Metafizyka, przeł. K. Leśniak, Warszawa 1984². Podobne teksty można znaleźć u Platona w dialogach: Kratylus (385b2o), Wrocław 1990 oraz Sofista (262 E-263 D), Warszawa 2010. 
(faktami, sytuacjami). Ta wypowiedź określana jest czasem jako „semantyczna” wersja KKP, natomiast istnieje również „metafizyczna” wersja KKP, którą znajdujemy w Metafizyce (q10, 1051b24): „Oto czym jest prawda: styczność z rzeczą i twierdzenie jest prawdą" ${ }^{2}$. Chodzi w tym tekście o przypadek połączenia podmiotu $z$ atrybutem. Wtedy można mówić o prawdzie lub fałszu. Gdy zaś mamy do czynienia tylko z pojęciem, nie ma wtedy miejsca prawda, lecz tylko wiedza lub niewiedza. „Kto więc myśli o rozdzielonym, że jest rozdzielone, a o połączonym, że jest połączone, mówi prawdę"3. Nie można stosować prawdy i fałszu do tego, co koniecznie ma jakąś cechę, bo wtedy nie ma alternatywy. Co do rzeczy przygodnych, zdanie (opinia) raz będzie prawdziwe, kiedy indziej fałszywe. Pokrewne miejsce znajduje się w De Interpretatione (16a9-16), gdzie rozważna jest relacja pomiędzy rzeczami (faktami) a upodobnionymi (homoiomata) do nich myślami ${ }^{4}$. Odróżnia tam Stagiryta zdania od pojęć i ich nazw. Tylko zdania są prawdziwe lub fałszywe.

Za drugie zaś źródło uchodzi następujący tekst św. Tomasza z Akwinu, choć nie jest to jedyne takie miejsce u Akwinaty: „Skoro bowiem prawda intelektu to zgodność intelektu i rzeczy (adaequatio rei et intellectus) ${ }^{5} \mathrm{w}$ tej mierze, w jakiej intelekt twierdzi, że jest to, co jest, lub że nie ma tego, czego nie ma, to prawda w intelekcie odnosi się do tego, co intelekt twierdzi, a nie do czynności, przez którą to twierdzi” [podkr. A. O.] ${ }^{6}$.

2 Arystoteles, Metafizyka, dz. cyt. O takim rozróżnieniu wspomina np. M. David, The Correspondence Theory of Truth, ed. E. N. Zalta, w: The Stanford Encyclopedia of Philosophy (Fall 2016 Edition), https://plato.stanford.edu/archives/fall2016/entries/truth-correspondence/ (20.10.2020). Por. P. Crivelli, Aristotle on Truth, Cambridge 2004.

3 Arystoteles, Metafizyka, dz. cyt., $1051 \mathrm{~b}$.

4 Por. C. W. A. Whitaker, Aristotle's „De Interpretatione”: Contradiction and Dialectic, Oxford 2007, s. 9 (Oxford Aristotle Studies) i o takim podobieństwie wspomina (M. David, The Correspondence Theory of Truth, dz. cyt.).

W dalszej części dla oznaczenia tej definicji będę używał skrótu: AIR.

6 „Cum enim veritas intellectus sit adaequatio intellectus et rei, secundum quod intellectus dicit esse quod est vel non esse quod non est, ad illud in intellectu veritas pertinet quod intellectus dicit, non ad operationem qua illud dicit" (S. Thomas, Summa contra gentiles, lib. 1 cap. 59 n. 2, tłumaczenie za: Stanisław Judycki, Rozdział XIV: Prawda, s. 5-6 [draft części książki]). W tej pracy można znaleźć syntetyczne ujęcie całego zagadnienia prawdy oraz ciekawe uwagi historyczne na temat prawdy. Por. także inne miejsca u Akwinaty: „Et sic veritas non est virtus, sed obiectum vel finis virtutis. Sic enim accepta veritas non est habitus, quod est genus virtutis, sed aequalitas quaedam intellectus vel signi ad rem intellectam et significatam, vel etiam rei ad suam regulam, ut in primo habitum est" (STh II-IIae, q. 109, a. 1), zob. także: STh I a. 16, 1 co., 22 arg. 2; q. 21, a. 2, co.; q. 95, a 9 arg. 2; II-IIae, q. 110, a. 2 co. oraz „(...) ubi primo veritas invenitur, hoc est in intellectu” (STh I, 
Dokładniejsze przyjrzenie się całej sprawie pozwala stwierdzić, że sytuacja jest nieco inna od przedstawianej zwyczajowo w podręcznikach. Jeśli chodzi o koncepcję prawdy (KKP) u samego Arystotelesa, to sprawa jest dość jasna i jej autorstwo nie podlega żadnej dyskusji, choć, jak już wspomniano, podobne sformułowania pojawiają się u nauczyciela Stagiryty - Platona. Natomiast kwestia autorstwa definicji przypisywanej Tomaszowi (tzn. AIR) jest bardziej złożona, o czym wspomniał sam Akwinata, przypisując autorstwo - prawdopodobnie mylnie ${ }^{7}$ - Izaakowi Israeliemu. Dzisiaj niektórzy wskazują na sformułowanie literalnie bliskie KKP, które można znaleźć u Awicenny ${ }^{8}$, a które, co bardzo prawdopodobne, pochodzi ze starożytności m.in. od sceptyka Karneadesa i neoplatonika Proklosa9. Tomasz Pawlikowski ${ }^{10}$, który zajął się tą sprawą dokładniej, wskazuje na pojawienie się literalnego sformułowania AIR w dorobku Filipa Kanclerza (ok. 117o-1236), zaś zaprzecza, by $u$ Awicenny chodziło o to samo sformułowanie ${ }^{11}$. Ponieważ nasza praca nie ma charakteru historycznego i nie chcemy wchodzić w te spory lub szczegóły, odsyłamy zainteresowanych do innych prac wskazanych na końcu w bibliografii, a my przejdziemy co prędzej do dalszej części, zapamiętując ustalenie, że KKP nie jest oryginalnym pomysłem Akwinaty, lecz została przejęta i była przedmiotem jego komentarzy. Dodatkowo, badania wskazują raczej na to, że pytanie o oryginalność AIR w sformułowaniu Tomasza ma odpowiedź negatywną, jeśli chodzi o literę, zaś pozytywną, jeśli chodzi

q. 17, a. 1 co.), czy także "Dictum est autem supra quod credere est actus intellectus secundum quod movetur a voluntate ad assentiendum, procedit enim huiusmodi actus et a voluntate et ab intellectu“ (STh II-IIae q. 4, a. 2 co.). Por. także: T. Bartel, Nowa interpretacja definicji „Veritas est adaequatio rei et intellectus” u świętego Tomasza z Akwinu, „Studia Philosophiae Christianae” 25 (1989) nr 2, s. 194-199; M. David, The Correspondence Theory of Truth, dz. cyt.; J. Woleński, Historia pojęcia prawdy, w: Przewodnik po epistemologii, red. R. Ziemińska, Kraków 2013, s. 53-86.

7 Pawlikowski twierdzi, że być może Tomaszowi chodziło o sens definicji, który znajdujemy u Israeliego, a nie literalne brzmienie, które tam nie występuje.

8 Zob. Avicenna, Metafisica, con testo arabo e latino, a cura di O. Lizzini e P. Porro, Milano 2002, cap. I, sec. 8, s. 107: „Veritas autem quae adaequatur rei, illa est certa, sed est certa, ut puto, respect suae comparationis ad rem, et est veritas respectu comparationis rei ad ipsam".

9 Por. M. David, The Correspondence Theory of Truth, dz. cyt.

10 T. Pawlikowski, „Liber de definicionibus” i scholastyczny problem „adaequatio”, „Rocznik Tomistyczny” 4 (2015), s. 100.

${ }^{11}$ Por. T. Pawlikowski, „Liber de definicionibus” i scholastyczny problem „adaequatio”, dz. cyt., s. 97-99. Bartel podtrzymuje wersję z Awicenną - zob. T. Bartel, Prawda i byt. Ujęcie prawdy ontycznej, w: „Quaestio disputata de veritate” świętego Tomasza z Akwinu, Złotoria 2008, s. 94. 
o jej sens ${ }^{12}$. Tomasz Bartel tak pisze w kwestii „nowości” interpretacji Tomaszowej: „W sposób konsekwentny ujmuje on prawdę, metafizycznie rzecz biorąc, jako relację rzeczy do jakiegoś intelektu, przedstawiając kolejno różne znaczenia terminów: res i intellectus"' ${ }^{\prime \prime}$. Poza tym Akwinata miał chcieć, by wedle jego definicji było miejsce na mówienie na przykład o prawdziwym przyjacielu, czy też prawdziwym pieniądzu, czyli o prawdzie bytu $^{14}$. Podsumowując to za pomocą metafory budowli, można powiedzieć, że KKP jest budowaną od starożytności konstrukcją, w której św. Tomasz miał znaczący udział w postaci nowej wersji AIR, i do niej właśnie my także chcemy dołożyć swoją cegiełkę.

\section{Etymologia terminu adaequatio}

Rozważany termin adaequatio należy do języka łacińskiego i pochodzi od dwóch wyrażeń: ad (po polsku „do”) oraz aequatio (po polsku „bycie równym w stosunku do czegoś innego") ${ }^{15}$. Samo tłumaczenie całego terminu w postaci kalki językowej „adekwacja” nie wnosi niczego ciekawego, choć ze względu na wygodę będziemy się nim dalej posługiwać. Sam św. Tomasz w pracy De veritate używał pięciu, zbliżonych znaczeniowo, terminów na adekwację, takich jak: „odpowiedniość” (correspondentia), „Zgodność” (cohaerentia), „upodobnienie” (assimilatio), „porównanie” (comparatio) i „dostosowanie, czyli zrównanie” (conformitas) $^{16}$. Dodatkowo warto odnotować, że, dla przykładu, angielskie tłumaczenie AIR, chyba niezbyt szczęśliwe, wygląda następująco: „[t]ruth is the equation of thing and intellect" i zawiera słowo equation, które ma dość mocne logiczne znaczenie np. w matematyce ${ }^{17}$. Jednak Pawlikowski przestrzega, że

${ }^{12}$ Skutecznie zwrócił moją uwagę na ten problem i jego subtelność T. Bartel, Nowa interpretacja definicji..., dz. cyt., s. 194-199).

${ }_{13}$ T. Bartel, Prawda i byt. Ujęcie prawdy ontycznej, dz. cyt., s. 93.

${ }^{14}$ To nawiązuje do obecnego w niektórych opracowaniach podziału na prawdę epistemologiczną i ontologiczną.

${ }^{15}$ Por. T. Pawlikowski, „Liber de definicionibus” i scholastyczny problem „adaequatio”, dz. cyt., S. 100.

${ }_{16}$ Por. Tomasz z Akwinu, Dysputa o prawdzie: dysputy problemowe o prawdzie. Kwestia 1, przekł. A. Białek, Lublin 2018, q. 1, a. 1, corpus; podaję za: T. Bartel, Prawda i byt. Ujęcie prawdy ontycznej, dz. cyt., s. 103-104. Antoni Stępień zaproponował dodatkowo termin „dorównanie”, jako tłumaczenie polskie dla łacińskiej adaequatio.

${ }_{17}$ Por. M. David, The Correspondence Theory of Truth, dz. cyt. Symbol równości, w obrębie logiki klasycznie rozumianej, syntaktycznie wiąże terminy kategorii nazwowej, które od strony 
sposób użycia omawianego terminu u św. Tomasza jest znacząco inny i wyraża „(...) niepełność zrównania lub odpowiedniości dwu zestawianych ze sobą w relacji adekwatności elementów, mianowicie intelektu oraz rzeczy"18. Jest to oczywiście w zgodzie z pewnymi tekstami św. Tomasza i innych komentatorów.

\section{Rozumienie AIR u św. Tomasza}

Rozumienie AIR Akwinaty zaskakuje nas swoją złożonością, nietrywialnością i, rzekłbym, paradoksalnością, czyli posiadaniem pewnych własności, które stoją w sprzeczności z potocznym mniemaniem. Wymienimy tutaj trzy własności prawdy, które są pochodną rozważań Tomasza. Pierwszą z nich jest to, że prawda jest wcześniejsza od poznania i nawet nie jest $\mathrm{z}$ nim, jako adekwacja, koniecznie związana, gdyż mówi Akwinata w De veritate: „bytowość rzeczy wyprzedza pojęcie prawdy, poznanie zaś jest jakimś prawdy skutkiem” [podkr. A. O.] $]^{19}$. Drugim, równie poważnym, ustaleniem jest to, że adekwacja jest pewnym procesem, jest jakby „rodzeniem się prawdy”, czyli ma charakter dynamiczny, a nie statyczny, jak wielu filozofów sądzi, twierdząc, że zachodzi bądź nie zachodzi ${ }^{20}$. Po trzecie zagadnienie prawdy umieszcza Akwinata nie na poziomie intelektu rozumianego w funkcji składającej i rozdzielającej, którego skutkiem są sądy prawdziwe i fałszywe, czyli tego intelektu (czy też funkcji), dzięki któremu dokonuje się cała praca intelektualna: sądzenia, rozumowania, tworzenia pojęć; raczej na poziomie intelektu „czytającego” quidditas (istotę) rzeczy (intus legere), bądź jeszcze wcześniej, kiedy intelekt możnościowy jest pobudzany przez byt, to znaczy gdy przyjmuje przedmioty poznania, które aktualizuje intelekt czynny ${ }^{21}$. Ta trzecia sprawa jest dla naszych rozważań

semantycznej posiadają te same denotacje, choć mogą posiadać różne sensy.

18 T. Pawlikowski, „Liber de definicionibus” i scholastyczny problem „adaequatio”, dz. cyt., s. 101.

19 Tomasz z Akwinu, Dysputa o prawdzie: dysputy problemowe o prawdzie, q. 1, a. 1, corpus; "Sic ergo entitas rei praecedit rationem veritatis, sed cognitio est quidam veritatis effectus" (Tomasz z Akwinu, Dysputa o prawdzie: dysputy problemowe o prawdzie, dz. cyt., s. 26). W innym miejscu pisze Tomasz, że „istnienie rzeczy jest przyczyną prawdy” (za T. Bartel, Prawda i byt. Ujęcie prawdy ontycznej, dz. cyt., s. 95).

${ }_{20}$ Por. T. Bartel, Prawda i byt. Ujęcie prawdy ontycznej, dz. cyt., s. 105.

${ }^{21}$ Por. T. Bartel, Prawda i byt. Ujęcie prawdy ontycznej, dz. cyt., s. 97, 107-108. Także P. Mazur, O nazwach intelektu, Lublin 2004, s. 67-68, 72nn. Źródłem u Akwinaty jest tekst z De anima, q. 1, a. 4., c.: „(...) jeśli więc intelekt możnościowy ma być pobudzany przez przedmiot poznania umysłowego, to taki przedmiot musi powstać dzięki intelektowi. Ponieważ coś, co jest w możności do jakiegoś bytu, nie może być jego czynnikiem aktualizującym, więc oprócz intelektu możnościowego należy 
szczególnie istotna, gdyż AIR wchodzi w grę pomiędzy rzeczą i intelektem znacznie wcześniej w sensie genetycznym, niż się powszechnie sądzi. Przyjrzyjmy się zatem nieco bliżej temu ostatniemu zagadnieniu, które już częściowo zostało wspomniane we wcześniejszych paragrafach. Najpierw wróćmy do kwestii pierwszej z De veritate, której fragment przytoczono powyżej, bo bezpośrednio przed nim Tomasz podaje inne określenia na adekwację, a wśród nich „upodobnienie” (assimilatio) oraz „dostosowanie, czyli zrównanie” (conformitate sive adaequatio). To pierwsze zachodzi w umyśle biernym (możnościowym) na skutek oddziaływania nań dowolnego przedmiotu zewnętrznego ${ }^{22}$. Zaś drugie to adekwacja w sensie właściwym. Według interpretacji Bartela ${ }^{23}$ św. Tomasz rozważał również w dziele De potentia cztery możliwe rozumienia czegoś, co umysł może rozumieć, czyli terminu res. Interpretacja Bartela nie jest całkowicie przekonująca, gdyż w samym tekście Tomasz nie używa czterokrotnie słowa res, a to coś określa innymi słowami. Jest oczywiste, że Akwinata pisał to w innym kontekście, bo w ósmej kwestii dyskutował sprawę relacji zachodzących w Bogu i między Bogiem a stworzeniem. Przy okazji uogólnił rozważania na relacje dowolne zachodzące pomiędzy dowolnymi obiektami, czyli czymś, co może być przez umysł rozumiane. To właśnie te obiekty rozważane były jako ujmowalne przez umysł rozumiejący ${ }^{24}$. Jednak kiedy bliżej się przyjrzeć Tomaszowym analizom, można przychylić się do interpretacji Bartela. Bowiem poczyniona tam dystynkcja ma, według nas, swoje konsekwencje, dla rozumienia adekwacji, czyli dla rozumienia relacji zachodzącej pomiędzy rzeczą a intelektem, co było związane z tzw. „kresami relacji” adekwacji ${ }^{25}$. Oto owe cztery przypadki wyznaczone przez cztery rozumienia res przez intellectus:

i. to rzeczy realne, zewnętrzne, poza strukturą poznawczą;

ii. to species, umysłowe formy poznawcze;

przyjąć intelekt czynny, który ma aktualizować przedmioty poznania umysłowego pobudzające intelekt możnościowy" (cyt. za: P. Mazur, O nazwach intelektu, dz. cyt., s. 74, przyp. 73 i 74).

${ }^{22}$ Por. T. Bartel, Prawda i byt. Ujęcie prawdy ontycznej, dz. cyt., s. 104.

${ }^{23}$ Zob. T. Bartel, Nowa interpretacja definicji..., dz. cyt., s. 198.

${ }^{24}$ Zob. Sancti Thomae de Aquino, Quaestiones disputatae de potentia, q. 8 a. 1 co, https:// www.corpusthomisticum.org/qdp8.html (10.02.2021).

25 Tutaj ciekawa uwaga odnosząca się do zaprezentowanego rozumienia relacji u tomistów, które chyba wywodzą bezpośrednio od Akwinaty. W szeroko rozumianej tradycji filozofii analitycznej relacja jest rozumiana odmiennie - jako obiekt teoriomnogościowy, czyli na przykład jako zbiór par uporządkowanych, w przypadku relacji binarnej. Ta różnica często utrudnia bądź nawet uniemożliwia porozumienie $\mathrm{z}$ tomistami. 
iii. to sam proces poznawania przez intelekt, intelekt $\mathrm{w}$ samorefleksji poznaje swój proces poznawania, a szczególnie siebie samego jako władzę aktu poznania przedmiotu;

iv. to pojęcie intelektu, jako wytwór samego intelektu ${ }^{26}$.

Akwinata odróżnia starannie czwarte rozumienie od pozostałych rozumień rzeczy. Z naszego punktu widzenia ważne jest odróżnienie pojęcia intelektu od species, czyli przypadku drugiego. Jako główne odmiany Mieczysław Gogacz wyróżnia species sensibilis oraz species intelligibilis, przy czym ta druga może być expressa lub impress $a^{27}$. Dla Gogacza ${ }^{28}$ species jest bytem poznawanym ujętym w roli oddziaływania na podmiot poznawczy i - za Tomaszem - nie jest „(..) czymś osobnym, czymś odrębnie bytującym poza władzami poznania, samodzielnym, substancjalnym. Jest stanem władz poznania (...)”. Święty Tomasz pisze w kontekście powyższej dystynkcji tak: „[o]d formy poznawczej [czyli species: A. O.] różni się [pojęcie: A. O.] zaś tym, że formę poznawczą, która aktualizuje intelekt, ujmuje się jako zasadę działania intelektu, gdyż każdy działający działa, o ile jest w akcie, a jest aktualizowany przez jakąś formę, która musi być zasadą działania”29. „Umysłowe formy poznawcze” (species intelligibiles), o których pisze Wojciech Daszkiewicz ${ }^{30}$, że „nie są przedmiotem intelektu", gdyż są tym, przez co [quo intelligit] poznajemy, a nie tym, co [quo intellegitur] poznajemy; my - czyli intelekt. Jeśli termin „przedmiot intelektu” nie posiada jakiegoś nieznanego mi znaczenia technicznego w systemie tomizmu, to wypada mi się z tym poglądem Daszkiewicza nie zgodzić. I chyba przytoczona dystynkcja św. Tomasza z O woli Bożej, również sprzeciwia się temu poglądowi. Ujmując to jeszcze inaczej i szerzej: o obiektach wyróżnionych w punktach (ii)-(iv), jak również o innych znajdujących się w intelekcie, można mówić res intellectus - „rzecz(y) intelektu”. Natomiast intelekt może być rozumiany dwojako: bądź jako „władza duszy w pewnym akcie” bądź

${ }^{26}$ T. Bartel, Prawda i byt. Ujęcie prawdy ontycznej, dz. cyt., s. 100; Sancti Thomae de Aquino, Quaestiones disputatae de potentia, q. 8 a. 1 co.: „Intelligens autem in intelligendo ad quatuor potest habere ordinem: scilicet (1) ad rem quae intelligitur, (2) ad speciem intelligibilem, qua fit intellectus in actu, (3) ad suum intelligere, et (4) ad conceptionem intellectus" (numery w nawiasach dodane: A. O.). Por. również T. Bartel, Nowa interpretacja definicji..., dz. cyt., s. 198-199.

${ }_{27}$ Zob. M. Gogacz, Doprecyzowanie problemu „species”, „Studia Philosophiae Christianae” 31 (1995) nr 2, s. 70-72.

${ }_{28}$ Zob. M. Gogacz, Doprecyzowanie problemu „species”, dz. cyt., s. 69-7o.

29 Sancti Thomae de Aquino, Quaestiones disputatae de potentia, q. 8 a. 1 co.

3o W. Daszkiewicz, Intuicja intelektualna $w$ metafizyce, Lublin 2014, s. 108. 
jako „skutek, ujęcie rzeczywistości”. Wydaje mi się, że chodzi tutaj o intelekt czynny i intelekt możnościowy, ale nie jestem pewien, czy dobrze rozumiem tę dystynkcję w systemie św. Tomasza ${ }^{31}$. Z czysto kombinatorycznych wyliczeń mamy co najmniej osiem różnych rozumień AIR. Ta sytuacja jest w pewnym sensie wyzwaniem dla tomistów, gdyż ich analizy pism Mistrza, zamiast przynosić jakieś wyjaśnienia, mnożą tylko wątpliwości. Przez to trudno jest mówić o, przynajmniej częściowym, wykorzystaniu poglądów Akwinaty do rozwiązania problemów filozoficznych, które pojawiły się wiele lat po działalności twórcy tomizmu, jak np. teza Churcha, $\mathrm{z}$ których on sam nie zdawał sobie zupełnie sprawy. Notabene mógłby to być też dobry test sprawdzający wydolność tomizmu ${ }^{32}$. Nie dysponując wystarczającymi narzędziami, spróbujemy jednak podejść nieco bliżej do rozważanej sprawy. Korzystając z czterech powyżej wskazanych rozumień „rzeczy”, pomimo wskazanych trudności, podejmiemy próbę rozważania tezy Churcha w kontekście AIR. Uczynimy tak, przyjmując dwa ustalenia, zgodne zresztą z nauką św. Tomasza, jako wiążące w dalszej części pracy: (i) AIR wiąże rzecz z intelektem na głębokim poziomie, głębszym niż poziom samego języka; (ii) intelekt ma możliwość upodobnienia się do każdego bytu³.

\section{Koncepcja i główna teza pracy}

Po tych wstępnych, ale bardzo żmudnych, uwagach, przejdziemy do prezentacji pomysłu tej pracy, który jest dość prosty, oraz do przedstawienia głównej tezy artykułu. Sam pomysł wywodzi się ze skojarzenia AIR z tezą Churcha, prowadząc do porównania obu sformułowań:

${ }^{31}$ Por. T. Bartel, Prawda i byt. Ujęcie prawdy ontycznej, dz. cyt., s. 10o. Moje rozważania opieram w dużej mierze na pracach: T. Bartel, Nowa interpretacja definicji..., dz. cyt. i T. Bartel, Prawda i byt. Ujęcie prawdy ontycznej, dz. cyt. Autor ten urywa jednak swoje analizy w miejscu, gdzie właściwie sam problem z AIR się dopiero zaczyna, dlatego musimy tutaj pójść własną drogą. Należy jednak podkreślić, że Bartel wykonał poważną i wartościową pracę filozoficzną. O. prof. Stanisławowi Ziemiańskiemu zawdzięczam syntetyczne ujęcie tej sprawy: „Intelekt możnościowy - in potentia to tabula rasa, czyli oczekujący na uaktualnienie przez treść poznaną. Natomiast intelekt in actu ma już treść poznaną. Intelekt czynny jest umiejętnością obróbki treści dochodzących od zmysłów, abstrahuje, tworząc pojęcia ogólne" (prywatna korespondencja).

${ }^{32}$ Jako uczeń ks. prof. K. Kłósaka - neotomisty, jestem przekonany, że należałoby powtórzyć eksperyment z neotomizmem w obecnych okolicznościach, czyli około 100 lat po pierwszym, chyba jednak nieudanym, eksperymencie.

33 Ten pogląd uznawał Arystoteles i przejął go również św. Tomasz. 


\section{AIR versus $\mathrm{CT}^{34}$.}

W pracy postaramy się podać, nieco bardziej rozwinięty w stosunku do Tomaszowego, sposób rozumienia AIR, przez co zamierzamy ubogacić samą KKP. AIR zapiszemy najpierw symbolicznie, nie po to by ją sformalizować, co byłoby zadaniem beznadziejnym pewnie, lecz by ułatwić myślenie koncepcyjne o niej, w postaci ${ }^{35}$ :

$$
[\mathrm{AIR}] \text { Veritas }=_{\mathrm{df}}\left(\text { Res }=_{\text {adeq }} \text { Intellectus }\right) .
$$

Natomiast przez tezę Churcha rozumieć będziemy najmocniejsze ze znanych mi jej sformułowań. Dygresja o tezie Churcha: CT jest właściwie nazwą własną pewnej hipotezy, którą jako pierwszy sformułował amerykański logik Alonzo Church na przełomie 1934 i 1935 roku. Hipoteza ta ustala związek pomiędzy pojęciami: $\mathrm{z}$ jednej strony pomiędzy matematycznym pojęciem (całkowicie ścisłym) funkcji rekurencyjnej, a z drugiej strony pojęciem intuicyjnym funkcji efektywnie obliczalnej. Charakter tego związku jest niejasny, ale według moich badań nawiązujących do podstawowych prac Churcha ${ }^{36}$ jego najmocniejsza postać to swoista identyczność pojęć (do dzisiaj niesprecyzowana); słabszą wersją jest równoważność pojęć (tzn. identyczność ich ekstensji) bądź prosta identyczność dwóch zbiorów. Koniec dygresji. Konsekwentnie rozważamy CT w postaci pochodzącej ode mnie wersji, która ustala zależność pomiędzy pojęciem ogólnej (lub częściowej) funkcji rekurencyjnej [dalej: Con $_{\text {Rek }}$ ], a pojęciem intuicyjnym funkcji efektywnie obliczalnej [dalej: Con $_{\text {Efekt }}$ ]:

$$
[\mathrm{CT}]\left(\mathrm{Con}_{\text {Rek }}=\mathrm{Con}_{\mathrm{Efekt}}\right)^{37}
$$

${ }^{34}$ CT jest tutaj rozumiana dość szczególnie, tak jak zostało wprowadzone w książce: A. Olszewski, Teza Churcha. Kontekst historyczno-filozoficzny, Kraków 2009, rozdz. 5.

35 Należy zwrócić uwagę na zindeksowane symbole identyczności. Jeden z nich to identyczność definicyjna (spójka definicyjna), zaś druga to identyczność (równość) w sensie adekwacji. Trzeba jednak tutaj dodać, że użycie schematów, choć nie jest poprawną formalizacją, czego nie twierdzimy w żadnym razie, nie jest całkiem bezpłodne, gdyż może prowadzić intuicję na właściwe tory. Ten typ swoistych formalizmów, o ile wiem, nigdzie nie został ogólnie opisany, a posiada on niezaprzeczalny walor poznawczy.

${ }^{36}$ Por. A. Olszewski, Teza Churcha. Kontekst historyczno-filozoficzny, dz. cyt., rozdz. 5.

${ }^{37}$ Użyty tutaj znak identyczności lub równości ma niejasne znaczenie. Intuicyjnie jest to identyczność pomiędzy pojęciami. 
W tym miejscu musimy skorzystać z elementów filozofii matematyki św. Tomasza z Akwinu. Nie będziemy tej filozofii tutaj rozwijać, a zainteresowanego czytelnika odsyłamy do ciekawych prac Armanda Maurera ${ }^{38}$. Skupimy swą uwagę na bardzo ciekawym rozróżnieniu pochodzącym od Akwinaty, z dziełka nazwanego Questio disputata ${ }^{39}$, które pomimo pochodzenia z okresu dojrzałego (1265-1267) jego twórczości, autor włączył do komentarza do Sentecji Piotra Lombarda, czyli dzieła z lat 1252-1256, napisanego w Paryżu. W tym dziełku, czy lepiej fragmencie, znajdujemy bardzo ważne Tomaszowe rozróżnienie trzech sposobów odnoszenia się pojęć do rzeczywistości ${ }^{40}$. W pierwszym (I) sposobie pewne pojęcia odnoszą się wprost do pozaumysłowej rzeczywistości, jak np. człow iek, i przez podobieństwo gwarantują prawdziwość orzekania tego pojęcia o rzeczywistości. Trzeci (III) z wymienionych przez Tomasza sposobów dotyczy pojęć, określonych przez Akwinatę fałszywymi, które nie posiadają ani bliższego, ani dalszego podobieństwa do rzeczywistości, bo są owocem jakiejś władzy imaginacyjnej, jak np. pojęcie „chimera”. Natomiast dla naszych rozważań najważniejszą rolę pełni drugi (II) sposób odniesienia pojęć, które są częściowo podobne i wywodzące się rzeczywistości, a częściowo nie. Umysł adinvenit (wymyśla) tego typu pojęcia, a bazą dla ich utworzenia jest rzeczywistość pozaumysłowa oraz sam umysł, jak np. pojęcie genus (rodzaj) lub abstractio matematicorum, nie w sensie aktu matematyka, lecz w sensie wytworu takiego aktu abstrakcji ${ }^{41}$. Wydaje się, że w tym sensie można również rozumieć ważną uwagę ${ }^{42}$, kiedy pisze: „[i]intelekt ujmuje rzeczy we własny sposób, (...) ponieważ nie wszystko w poznaniu wchodzi do intelektu z zewnątrz" . Inną ważną sprawą są elementy filozofii matematyki Tomasza, które w skrócie przydatnym do naszych celów można scharakteryzować w ten

${ }^{38}$ A. Maurer, A Neglected Thomistic Text on the Foundation of Mathematics, w: A. Maurer, Being and Knowing: Studies in Thomas Aquinas and Later Medieval Philosophers, Toronto 1990, s. 33-41 (Papers in Mediaeval Studies, 10) i A. Maurer, Thomists and Thomas Aquinas on the Foundation of Mathematics, "Review of Metaphysics" 47 (1993), s. 43-61.

39 Por. A. Maurer, A Neglected Thomistic Text..., dz. cyt., s. 35. W Sentecjach ma ono sigla: I. Sent., d. 2, q. 1, a. 3; A. Maurer, A Neglected Thomistic Text..., dz. cyt., s. 35.

${ }^{40}$ Tomasz uważał to dziełko za bardzo ważne dla zrozumienia jego myśli. Por. A. Maurer, A Neglected Thomistic Text..., dz. cyt., s. 35 oraz A. Maurer, Thomists and Thomas Aquinas on the Foundation of Mathematics, dz. cyt., s. 53. W tym dziełku Tomasz wspomina również o tzw. ratio; to bardzo ciekawe ujęcie pojęć, wymagające osobnego opracowania.

${ }^{41}$ Por. A. Maurer, Thomists and Thomas Aquinas on the Foundation of Mathematics, dz. cyt., S. 53.

${ }^{42}$ Por. W. Daszkiewicz, Intuicja intelektualna $w$ metafizyce, dz. cyt., s. 98. 
sposób, iż Akwinata miał „realistyczną” koncepcję matematyki jako dyscypliny filozoficznej, która wraz z artes liberales miała przygotowywać do studiowania filozofii właściwej. Przede wszystkim przez matematykę rozumiał (fragmenty) arytmetyki liczb naturalnych oraz geometrię euklidesową ${ }^{43}$. Pierwszy z działów zajmował się mnogościami dyskretnymi, zaś drugi ciągłymi. Liczby naturalne same pochodziły z umysłu, lecz służyły do liczenia obiektów rzeczywistych. Dodatkowo zero i jeden nie były dla Akwinaty liczbami naturalnymi ${ }^{44}$. O realistyczności obiektów matematyki decydowała chyba zasada „nihil est in intellectu quo non fuerat in sensu”, czyli że wszystko, co w intelekcie, jakoś musi przejść przez zmysły. To jest uproszczona wersja poglądów pierwszego tomisty, ale konsekwentnie dotyczyło to matematyki, i podstawowe ilościowe związki wywodziły się z poznania zmysłowego. Maurer podsumowuje to w ten sposób, że: „[p]rzedmiot matematyki wydaje się pojawiać, jako realny byt substancjalny scharakteryzowany tylko przez formę ilości"45. Umysł natomiast potrafi, ze względu na swoje specyficzne własności, wytworzyć, być może skonstruować, z tych początkowych obiektów inne, bardziej złożone pojęcie. To właśnie ten drugi typ pojęć, które wcześniej wskazano, ma tutaj zastosowanie. Przytacza nawet takie opinie, które zostały sformułowane na podstawie lektury pism Akwinaty oraz literatury o nim, przypisujące św. Tomaszowi jakąś postać konstruktywizmu, czyli w tym kontekście poglądu, wedle którego obiekty matematyczne istnieją naprawdę w intelekcie czy też umyśle ${ }^{46}$. Na podstawie tej garści poglądów Tomasza z zakresu filozofii matematyki można powiedzieć, że ówcześnie bardzo trudne byłoby ukształtowanie się u Akwinaty ogólnego pojęcia funkcji rekurencyjnej lub funkcji efektywnie obliczalnej w sensie intuicyjnym. Natomiast pełniejsza wiedza matematyków, którą zdobyli w wieku XIX i na początku wieku XX, szczególnie dzięki badaniom Dedekinda, Fregego i Hilberta, pozwoliła na ukształtowanie się tych pojęć, i być może stało się to w sposób, o którym mówił św. Tomasz ${ }^{47}$. W wyniku pobieżnej analizy

43 Piszę tutaj ogólnie o fragmentach, gdyż nie wiadomo, jak rozumiał to św. Tomasz.

${ }_{44}$ Por. A. Maurer, Thomists and Thomas Aquinas on the Foundation of Mathematics, dz. cyt., s. 51. Ta sprawa jest ciekawa, gdyż, szczególnie z zerem, był jeszcze problem w wieku XIX np. $\mathrm{u}$ Dedekinda w książce: Was sind und was sollen die Zahlen, 1888.

${ }^{45}$ A. Maurer A., Thomists and Thomas Aquinas on the Foundation of Mathematics, dz. cyt., s. 49 .

${ }^{46}$ Por. A. Maurer, A Neglected Thomistic Text..., dz. cyt., s. 50, przyp. 31.

47 Rozwinięcie powstania arytmetyki liczb naturalnych i pojęcia funkcji rekurencyjnej znajdzie czytelnik w pracy Adama Olszewskiego (A. Olszewski, Teza Churcha. Kontekst historyczno-filozoficzny, dz. cyt.) w pierwszej części. Poglądy św. Tomasza na temat obiektów matematyki, szczególnie liczb 
wygląda na to, że pojęcie Con $_{\text {Rek }}$ pochodzi, używając klasyfikacji odniesienia pojęć do rzeczywistości wg św. Tomasza, ze świata rzeczywistego i należy do pierwszego lub drugiego typu pojęć. Wyrażone dubium pochodzi stąd, że nie jest rozstrzygnięte rozumienie arytmetyki liczb naturalnych u Tomasza, ale wydaje się, że raczej chodzi o drugi typ pojęć. Natomiast z pojęciem Con $_{\text {Efekt }}$ sprawa wydaje się bardziej skomplikowana. Postawię tutaj nieco ryzykowaną hipotezę (która wymagać będzie badań), że jest ono pojęciem typu drugiego, używając podziału Tomaszowego. Nie umiem powiedzieć, czy w pismach Akwinaty można znaleźć głębsze analizy tego typu sposobu odnoszenia się pojęć do rzeczy(wistości) rozumianej szerzej, ale wydaje się, że teoretycznie bez trudu można by wyróżnić całą gamę takich odniesień, na przykład ze względu na „wielkość” uzależnienia pojęcia od rzeczywistości zewnętrznej, i, z drugiej strony, ze względu na „wielkość” komponentu intelektualnego zawartego $\mathrm{w}$ jego tworzeniu ${ }^{48}$. Jeśli jednak weźmiemy pod uwagę cztery rozumienia res u św. Tomasza, które wyróżnił w późnym piśmie De potentia, to znajdziemy tam także rozumienie jako res pewnych obiektów intelektu, jako jego pojęć (por. szczególnie punkty (iii-iv)), a nawet jakoś jako samego intelektu. W tej

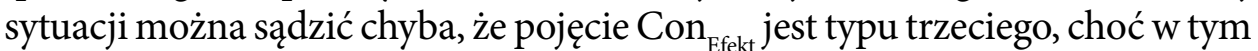
przypadku rzeczywistością (res w sensie (iv)) byłyby pojęcia umysłu. Tak czy inaczej, pojęcia Con Rek $_{\text {i Con }}$ Efekt różnią się w podanym ujęciu sposobem ich utworzenia.

Dla ułatwienia rozumienia tego zagmatwanego etapu rozważań posłużmy się wprowadzonymi schematami. I tak, kiedy do schematu AIR, na mocy drugiego, trzeciego i czwartego rozumienia rzeczy (res), za res podstawimy res intellectus, w znaczeniu, które wprowadziliśmy powyżej (sekcja 3.), to uzyskamy schemat ${ }^{49}$ :

[AIR1] Veritas $=_{\mathrm{df}}\left(\right.$ Res Intellectus $=_{\text {adeq }}$ Intellectus $)$.

naturalnych, pozwalają rzucić nieco światła na znacznie późniejszą krytykę poglądów Milla przez Fregego na temat genezy liczb naturalnych. $Z$ obecnej perspektywy tomistycznej wydaje się, że rację miał Mill, a nie Frege.

${ }^{8}$ Oczywiście, te rozważania są bardzo ogólne i słabo uzasadnione. Mają raczej charakter dygresyjny. Jest to konsekwencja braku, o ile wiem, rozwiązania zarówno tego problemu, jak i braku przesłanek do tego celu.

49 Takie postawienie sprawy jest związane z postulatem, by sam intellectus stawiać na miejscu rzeczy, czyli przedmiotu poznania. Akwinata explicite dopuszczał możliwość samorefleksji intelektu por. na przykład De potentia, q. 8 a. 1, co., gdzie św. Tomasz pisze: „Cum vero intellectus seipsum intelligit, verbum praedictum, sive conceptio, eiusdem est propago et similitudo, scilicet intellectus seipsum intelligentis". 
Bardziej ogólny sens ma schemat:

[AIR2] Veritas $=_{\mathrm{df}}\left(\right.$ Intellectus ${ }_{\text {adeq }}$ Intellectus $)$.

Mamy tutaj dwa podprzypadki AIR, wedle których prawda to zgodność rzeczy intelektu z intelektem („Veritas est adaequatio intellectus et intellectus” lub „Veritas est adaequatio rei intellectus et intellectus”). AIR2 wydaje się konieczna do uzyskania adekwacji, której nie można uzyskać z AIRı, jaka zachodzi pomiędzy intelektem wziętym jako całość a samym intelektem. Czy coś takiego dopuszcza nauka św. Tomasza $?^{50}$ Ktoś mógłby kwestionować to ujęcie, na przykład zarzucając, iż w ten sposób prawda się trywializuje, co byłoby, jak sądzę, sprzeczne z poglądem Akwinaty. Broniąc tego ujęcia prawdy, podkreślmy z dużym naciskiem, że umysł też ma swoje obiektywne właściwości, które filozof może próbować wyrazić lub nawet powinien opisaćs1. Z pewnością św. Tomasz był tego świadom ${ }^{52}$. Jeżeli jednak dopuścimy taką konsekwencję, i będzie ona w ogóle do przyjęcia w obrębie systemu tomistycznego, co wydaje się możliwe na podstawie wcześniejszych rozważań, to będziemy mogli dodatkowo przyjąć jako wnioski:

[CT1]

[CT2]

[CT3] $\left(\right.$ Con $_{\text {Rek }}={ }_{\text {adeq }}$ Con $\left._{\text {Efekt }}\right)$;

$\left(\mathrm{Con}_{\mathrm{Rek}}={ }_{\text {adeq }}\right.$ Intellectus);

$\left(\right.$ Con $_{\text {Efekt }}={ }_{\text {adeq }}$ Intellectus).

Tutaj CT2 jest instantacją AIR lub AIR1, zaś CT3 pochodną AIR1 lub lepiej AIR2. Dodatkowo CT2 i CT3 są podstawą do uznania CT1. Powyżej sformułowana „równość" CT1 jest o tyle ciekawa, że pozwala zrozumieć, na czym właściwie polega identyczność ze schematu CT, której natura była dotychczas nieznana, a w wyniku obecnych rozważań w kontekście zasad filozofii św. Tomasza z Akwinu pokazałaby się nam jako szczegółowy przypadek adekwacji. Gdyby tak było rzeczywiście, to byłby to wynik godny publikacji ${ }^{53}$.

${ }^{50}$ Por. w tej sprawie uwage Bartela, który raczej to wyklucza - zob. T. Bartel, Prawda i byt. Ujęcie prawdy ontycznej, dz. cyt., s. 101.

${ }^{51}$ Moje nieustanne zdziwienie budzi to, że niektórzy kompletnie nie chcą przyjąć takiego poglądu na temat intelektu homo sapiens.

${ }_{52}$ Zob. Sancti Thomae de Aquino, Quaestiones disputatae de potentia, q. 8 a. 1 co.

53 Propozycja skierowana do tomistów, a zawarta w niniejszej pracy, jest daleko idąca i, jak sądzę, atrakcyjna, gdyż adekwacja Tomaszowa miałaby odgrywać rolę „równości” pomiędzy obiektami mentalnymi. 
Podkreślmy powtórnie, że nietrywialność tej adekwacji, pomimo że dotyczy wyłącznie pojęć, czyli obiektów intelektu, polega na stwierdzeniu zachodzenia relacji między pojęciami należącymi do różnych typów, wymienionych powyżej, o czym należy pamiętać. Mówiąc jeszcze inaczej: Con ${ }_{\text {Rek }}$ pochodzi

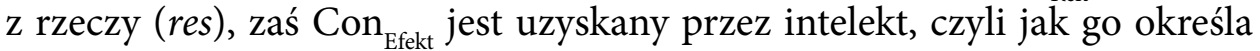
Daszkiewicz $^{54}$ - podmiot intuicji, na drodze samorefleksji mającej za swój przedmiot rozmaite pojęcia tegoż samego intelektu ${ }^{55}$. Dzięki temu można zachować i dyskutować sensowność oryginalnego sformułowania, którym posłużył się Church w sformułowaniu swej tezy, gdy mówił o „intuicyjnym pojęciu” $i$ "funkcji efektywnie obliczalnej w sensie intuicyjnym" ". Biorąc pod uwagę myśl Tomaszową, że „poznanie jest skutkiem prawdy”, rozumianej jako adekwacja, oraz wyniki naszych rozważań na temat adekwacji wyrażone w postaci AIR1 i AIR2, moglibyśmy zaryzykować tezę:

$\left[\mathrm{AIR}_{3}\right] \quad\left(\left(\mathrm{Con}_{\mathrm{Rek}}={ }_{\text {adeq }} \mathrm{Con}_{\text {Efekt }}\right)={ }_{\text {adeq }}\right.$ Intellectus $)$.

Przeciwko temu sformułowaniu można podnieść mocny, jak się zdaje, argument. Otóż relacja adekwacji nie zachodzi prawdopodobnie pomiędzy faktami a intelektem. Nie mogę podać definicji faktu, ale chodzi o ten jego aspekt, który odróżnia go od rzeczy. W potocznym użyciu fakt można nazwać „stanem rzeczy”. Jeśli byśmy zaliczyli tak rozumiane fakty do res, występującej w AIR, to całą tę koncepcję prawdy Tomaszową strywializujemy. Zgodnie z moją wiedzą wygląda na to, że „adekwacja” jest relacją, i to relacją realną, wedle ujęcia Akwinaty. Relacje realne rozważał on w nawiązaniu do wyróżnienia przez Arystotelesa trzech rodzajów relacji: numerycznych, przyczynowych i psychologicznych. Akwinata przyjął zasadniczo ten podział i w kontekście relacji psychologicznych wyróżnił relacje kategorialne i relacje rozumu ${ }^{57}$. Relacje rozumu to takie, które są powołane przyczynowo przez rozum, zaś realne to takie, które powstają bez aktywności rozumu jako przyczyny, powstają z przyczyn

54 W. Daszkiewicz, Intuicja intelektualna w metafizyce, dz. cyt., s. 98.

55 Możliwość takiego postawienia sprawy tezy Churcha jest dla mnie szczególnie ważna, gdyż filozofia św. Tomasza wydaje się doskonałym narzędziem do mówienia o Tezie, w przeciwieństwie do większości współczesnych redukcjonistycznych filozofii.

${ }^{56}$ Ta sprawa jest przedstawiona bardzo skrótowo, ze względu na charakter niniejszej pracy. Rozwinięcie tego wątku będzie możliwe ewentualnie w przyszłości.

57 Trochę tę sprawę upraszczam. Por. D. Svoboda, Aquinas on real relation, „Theologica” 6 (2016), s. 151-153. W dziele Questiones disputates de potentia mowa jest o relacjach realnych i relacjach rozumu. 
rzeczywistych. W związku z tym powstaje pytanie o to, jakiego rodzaju relacją będzie relacja adekwacji ${ }^{58}$. Jak już powyżej sugerowałem, adekwacja nie jest spowodowana przez rozum lub intelekt, lecz przez byt realny - rzecz, choć być może tomiści mają inną opinię na ten temat. Tak czy inaczej relacja ta nie jest bytem substancjalnym; zaliczona została do kategorii przypadłościowych przez Arystotelesa, a po nim przez Tomasza, i głównie z tego powodu AIR3 nie jest (nawet) sensowna ${ }^{59}$. Natomiast sensowne jest rozważanie prawdziwości CT1 w stylizacji Arystotelesa z Metafizyki, która wyewoluowała w filozofii w postaci koncepcji Alfreda Tarskiego. Weźmy wobec tego pod uwagę schemat CT1 i zastosujmy do niego schemat tzw. T-równoważności [dalej: TR] leżącej u podstaw definicji prawdy Tarskiego. Mamy wtedy:

[TR] Zdanie „Con ${ }_{\text {Rek }}={ }_{\text {adeq }}$ Con $_{\text {Efekt }}$ jest prawdziwe wtedy i tylko wtedy, gdy Con $_{\text {Rek }}={ }_{\text {adeq }}$ Con $_{\text {Efekt }}$.

Teraz na podstawie TR wiemy, kiedy zdanie będące tezą Churcha jest prawdziwe, przy czym „prawdziwość” wypowiedzi (zdania) jest rozumiana w sensie Arystotelesowskiej Metafizyki, o którym to pojęciu wspomniałem we wstępnej części niniejszej pracy. Otóż jest ono prawdziwe, gdy zostanie spełniony wystarczający i konieczny warunek, którym jest adekwacja pomiędzy Con $\mathrm{Rek}_{\mathrm{R}}$ oraz Con $_{\text {Efekt }}$ Taka sytuacja stała się dla mnie powodem do podjęcia refleksji zawartej w niniejszej pracy. Spostrzegłem, że wychodząc od klasycznego rozumienia prawdziwości CT, zmuszeni jesteśmy do odwołania się do prawdziwości na głębszym poziomie ontologicznym, o którym mówi AIR. Inaczej mówiąc, prawdziwość CT, w klasycznym arystotelesowskim sensie, zachodzi wtedy i tylko wtedy, gdy zachodzi prawdziwość, czyli adekwacja pomiędzy dwoma pojęciami wymienionymi w CT (konsekwencja AIR). CT wiąże te dwa ujęcia prawdziwości.

${ }^{58}$ Tutaj można przywołać znowu Arystotelesa, który mówiąc w relacjach numerycznych wyróżnił pomiędzy obiektami pozostającymi w relacji: tożsamość (identyczność), podobieństwo i równość.

59 Por. S. Ziemiański, Relacja według Franciszka Suáreza SJ, „Rocznik Filozoficzny Ignatianum” 16 (2010), s. 35-70; autor stwierdza, że relacja kategorialna nie spełnia warunków kategorii przypadłości, dlatego nie jest bytem. Relacja transcendentalna zaś nie różni się od substancji. 


\section{Wnioski podsumowujące i zakończenie}

Powyższa praca jest dla mnie ciekawym doświadczeniem filozoficznym, gdyż w trakcie jej pisania i czytania literatury zdałem sobie sprawę, że w przypadku tezy Churcha splatają się w niej niejako dwa zupełnie odmienne ujęcia prawdy. Nie znając wystarczająco koncepcji św. Tomasza z Akwinu, rozumiałem jego definicję prawdy w daleko idącym uproszczeniu i sądziłem, że moja intuicja bazująca na CT i wspomnianej dwoistości prawdy potwierdzi się podczas tworzenia tego artykułu. Nie doceniłem jednak głębi myśli Akwinaty i okazało się, że św. Tomasz w AIR niejako „przewidział” miejsce na moje rozważania. Tomaszowe AIR jest bardzo głębokim ujęciem istoty prawdziwości. O dwóch dodatkowych rzeczach muszę wspomnieć: po pierwsze - w pewnym miejscach wykroczyłem poza ramy wyznaczone przez Akwinatę i nie jestem pewien, jaka jest tego wartość, stąd prowokacyjny podtytuł skierowany do tomistów; po drugie - wydaje się, że niniejsza praca posiada dość specyficzny sposób weryfikacji prawdziwości sformułowanych tez, gdyż nie jest nią odniesienie do rzeczywistości, lecz odniesienie do korpusu tomistycznego.

\section{ABSTRAKT}

Artykuł stawia sobie za cel, poprzez skorzystanie z bogactwa pojęciowego systemu filozofii św. Tomasza i z użyciem jego typu pojęć, sformułowanie ważnego zagadnienia współczesnej filozofii matematyki - tezy Churcha [CT]. Wskazany cel starano się najpierw uzyskać przez pogłębioną analizę Tomaszowego określenia prawdy jako „adaequatio rei et intellectus”. Analiza ta ujawniła wielkie bogactwo treści filozoficznych leżących u podstaw i ukazała jej nietrywialność. Efektem końcowym jest próba sformułowania tezy Churcha jako specyficznej instantacji definicji prawdy Tomasza. Wynik pracy jest niejednoznaczny i dlatego stanowi swoiste wyzwanie dla zwolenników tomizmu do dyskusji na ten temat.

\section{SŁOWA KLUCZOWE}

prawda, definicja, św. Tomasz z Akwinu, teza Churcha, pojęcie

\section{Abstract}

Truth and Church's Thesis - The Challenge to the Tomists.

This work aims to formulate an important issue of contemporary philosophy of mathematics - Church's thesis [CT] - by taking advantage of the richness of the conceptual 
system of St. Thomas' philosophy and using its type of notions. The indicated aim was first tried to achieve through an in-depth analysis of Thomas' definition of truth as "adaequatio rei et intellectus." This analysis revealed a great wealth of underlying philosophical content and showed its nontriviality. The final result is an attempt to formulate Church's thesis as a specific instance of Thomas' definition of truth. The result of the work is ambiguous and therefore it constitutes a specific challenge for the supporters of Thomism to discuss this topic.

\section{KeYWORDS}

truth, definition, St. Thomas Aquinas, Church's thesis, concept

\section{BIBLIOGRAFIA}

Arystoteles, Metafizyka (tekst grec.-łac.-pol.), tłum. T. Żeleźnik, red. A. Maryniarczyk, t. 1-2, Lublin 1996.

Avicenna, Metafisica, con testo arabo e latino, a cura di O. Lizzini, P. Porro, Milano 2002.

Bartel T., Nowa interpretacja definicji „Veritas est adaequatio rei et intellectus” úswiętego Tomasza z Akwinu, „Studia Philosophiae Christianae” 25 (1989) nr 2, s. 194-199.

Bartel T., Prawda i byt. Ujęcie prawdy ontycznej, w: „Quaestio disputata de veritate” świętego Tomasza $z$ Akwinu, Złotoria 2008.

Crivelli P., Aristotle on Truth, Cambridge 2004.

Cyciura P., Terminologia problemu przedmiotu intelektu $w$ dziełach św. Tomasza $z$ Akwinu, „Filo-Sofija” 1 (2001), s. 109-126.

Daszkiewicz W., Intuicja intelektualna w metafizyce, Lublin 2014.

David M., The Correspondence Theory of Truth, ed. E. N. Zalta, w: The Stanford Encyclopedia of Philosophy (Fall 2016 Edition), https://plato.stanford.edu/archives/ fall2016/entries/truth-correspondence/(20.10.2020).

Gogacz M., Doprecyzowanie problemu „species”, „Studia Philosophiae Christianae” 31 (1995) $\mathrm{nr}$ 2, s. 69-76.

Judycki S., Rozdział XIV: Prawda (Draft) [archiwum autora].

Maurer A., A Neglected Thomistic Text on the Foundation of Mathematics, w: A. Maurer, Being and Knowing: Studies in Thomas Aquinas and Later Medieval Philosophers, Toronto 1990, s. 33-41 (Papers in Mediaeval Studies, 10), DOI: 10.1484/J.MS.2.306646. Maurer A., Thomists and Thomas Aquinas on the Foundation of Mathematics, „, Review of Metaphysics" 47 (1993), s. 43-61.

Mazur P., O nazwach intelektu, Lublin 2004.

Olszewski A., Teza Churcha. Kontekst historyczno-filozoficzny, Kraków 2009. 
Olszewski A., About a mature theory of Fregean sense, „Logic and Logical Philosophy” 26 (2017), s. 417-428, DOI: http://dx.doi.org/10.12775/LLP.2016.030.

Pawlikowski T., „Liber de definicionibus” i scholastyczny problem „adaequatio”, „Rocznik Tomistyczny" 4 (2015), s. 97-112.

Svoboda D., Aquinas on real relation, „Theologica” 6 (2016), s. 147-172.

Tomasz z Akwinu św., Dysputa o prawdzie: dysputy problemowe o prawdzie. Kwestia 1, przekł. A. Białek, Lublin 2018.

Whitaker C. W. A., Aristotle's „De Interpretatione”: Contradiction and Dialectic, Oxford 2007 (Oxford Aristotle Studies).

Woleński J., Historia pojęcia prawdy, w: Przewodnikpo epistemologii, red. R. Ziemińska, Kraków 2013, s. 53-86.

Ziemiański S., Relacja według Franciszka Suáreza SJ, „Rocznik Filozoficzny Ignatianum" 16 (2010), s. 35-70. 